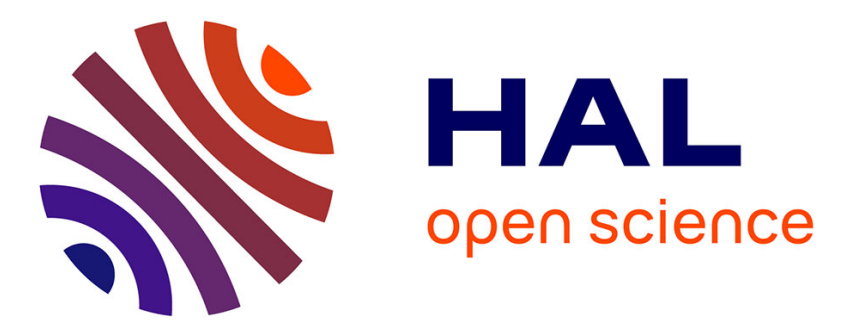

\title{
Locating an ancient anchorage at Tel Akko (Israel) using subsurface imaging: 2019 results
}

Logan Bergevin, Harry Jol, Ethan Sailer-Haugland, Michal Artzy, Yossi

Salomon, Matthieu Giaime, Gloria López, Armani Abu-Hmed

\section{- To cite this version:}

Logan Bergevin, Harry Jol, Ethan Sailer-Haugland, Michal Artzy, Yossi Salomon, et al.. Locating an ancient anchorage at Tel Akko (Israel) using subsurface imaging: 2019 results. 18th International Conference on Ground Penetrating Radar, Jun 2020, Golden, United States. pp.2-5, 10.1190/gpr2020002.1 . hal-03577121

\author{
HAL Id: hal-03577121 \\ https://hal.science/hal-03577121
}

Submitted on 27 Feb 2022

HAL is a multi-disciplinary open access archive for the deposit and dissemination of scientific research documents, whether they are published or not. The documents may come from teaching and research institutions in France or abroad, or from public or private research centers.
L'archive ouverte pluridisciplinaire HAL, est destinée au dépôt et à la diffusion de documents scientifiques de niveau recherche, publiés ou non, émanant des établissements d'enseignement et de recherche français ou étrangers, des laboratoires publics ou privés. 


\title{
Locating an Ancient Anchorage at Tel Akko (Israel) Using Subsurface Imaging: 2019 results
}

\author{
Logan Bergevin* (University of Wisconsin-Eau Claire), Harry Jol (University of Wisconsin-Eau Claire), Ethan \\ Sailer-Haugland (University of Wisconsin-Eau Claire), Michal Artzy (University of Haifa Leon Recanti \\ Institute for Maritime Studies), Yossi Salomon (University of Haifa Leon Recanti Institute for Maritime Studies), \\ Matthieu Giame (Durham University Department of Geography) Gloria I. López (Centro de Investagación \\ sobre la Evolución Humana), Armani Abu-Hmed (Israel Antiquities Authority)
}

\section{Summary}

Tel Akko, Israel is an ancient archaeological and UNESCO World Heritage site located along the dynamic Levantine coastline. Historical settlement of Tel Akko began 4,000 years ago along the northern coastline of the Haifa Bay. Between the Late Bronze age to the Hellenistic period, Tel Akko grew to become a well-connected port city. Geographically, the site benefitted due to its proximity to the Haifa Bay, connection to the Na'aman River Estuary, and the surrounding flat fertile Zevulon Plain. Nilotic (Nile) sediments carried northward by littoral drift prograded Tel Akko's coastline, causing an exodus from the site as it became landlocked. To identify possible anchorage sites, five grids were collected using ground penetrating radar (GPR) during the summer of 2019. A Sensors and Software pulseEKKO PRO 1000 GPR system was utilized to collect each grid, with an antennae frequency of $500 \mathrm{MHz}$. Survey collection occurred on the south and southwest embankments where marine and fluvial sands are most abundant in the sediment cores taken at Tel Akko. Data from previous years were analyzed to supplement and enhance earlier findings, as well as identify other features that could aid in understanding Tel Akko's development.

\section{Introduction}

Tel Akko, Israel was a historically significant harbor situated along Haifa Bay in northwest Israel from the Late Bronze Age (1550-1200 B.C.E.) to the Hellenistic period (323-32 B.C.E.; Figure 1; Giame et al., 2018). Haifa Bay lies at the northern terminus for Nilotic sediments and has undergone coastal changes due to littoral drift (Figure 2; Morhange et al., 2016; Zviely et al., 2007). Two rivers, the Na'aman and Kishon, drain into Haifa bay and deposit fine silts and clays along the coastline and estuary (Vachtman et al., 2012; Morhange et al., 2016). Aeolian sediment deposition in the region is predominantly controlled by dominant westerly winds, which create dune complexes (Porat et al., 2008). Sediment deposition into the Haifa Bay from littoral, fluvial (river) and aeolian (wind) inputs caused westward coastline progradation and decreasing estuary depth. The westward coastal progradation and silting up of the estuary severed Tel Akko's link to the Haifa Bay. Tel Akko's loss of access to the Mediterranean Sea rendered the anchorage obsolete, and the Tel was abandoned in the $2^{\text {nd }}$ century B.C.E. (Artzy, 2015).

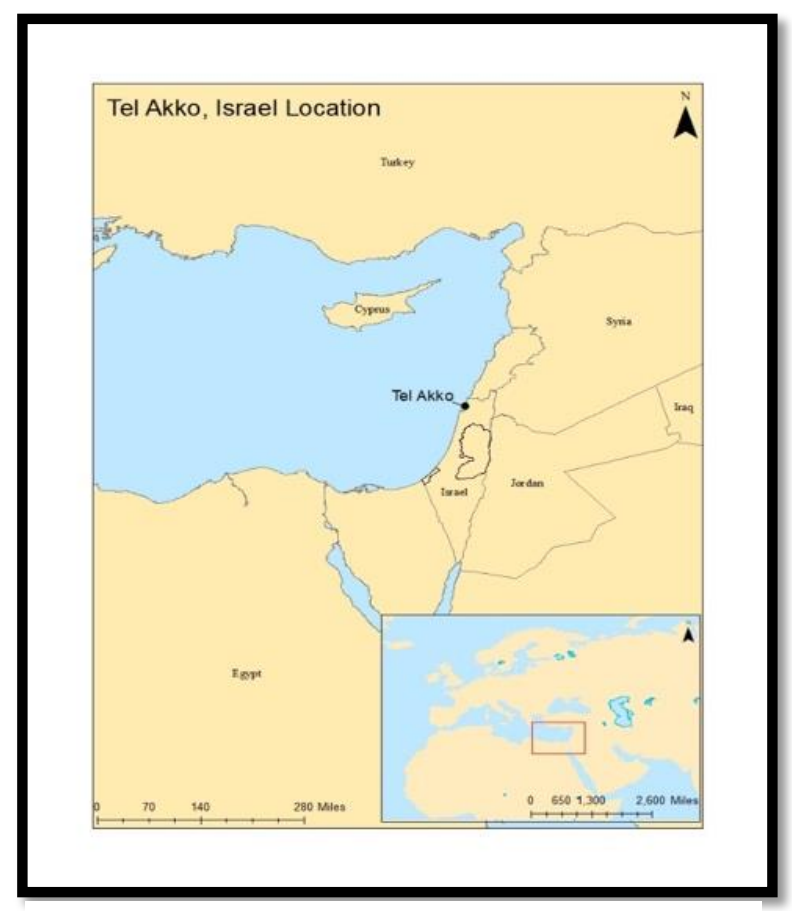

Figure 1: Locator map of Tel Akko, Israel

Archaeological excavations at Tel Akko began in 1976 and were led by Moshe Dothan. Dothan's and numerous other excavations at the site have revealed a major period of urbanization after $2000 \mathrm{BCE}$ and have uncovered an impressive rampart and sea gate. Funding for these construction projects came from Tel Akko's maritime trading partners which included Cyprus, Western Anatolia, Egypt, and the Aegean (Artzy, 2012). During the Summers of 2018 and 2019, ground penetrating radar surveys (GPR), cores, and drone imagery were collected at Tel Akko to locate archaeological features and the buried anchorage. Grid collection was confined to the south and southwest bases of the Tel, where sediment cores indicated the presence of marine sands (Giame et al., 2018). The purpose of this research was to identify possible locations of a harbor and any human-made features 


\section{Tel Akko, Israel Subsurface Imaging}

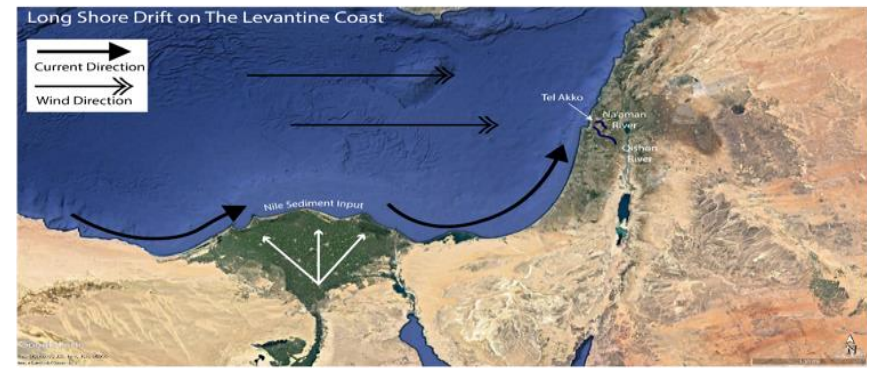

Figure 2: Sediment inputs are comprised of sediments from the Nile River which are carried to the northeast due to prevailing winds and currents. Other fluvial sediments are deposited from the Na'aman and Qishon Rivers (Zviely, 2006)

\section{Methods}

GPR can be used to investigate and identify human-made and/or geomorphic features based on the sediment's dielectric permittivity and electrical conductivity (Conyers and Goodman, 1997). GPR is a near-surface geophysical surveying technique which uses nondestructive electromagnetic wave pulses to image the subsurface (Jol and Bristow, 2003). Improvements in GPR instrument sensitivity and computational power have enhanced resolution and sampling rates (Bernd and Garrison, 2003). The advancement of GPR technology has allowed for new applications and research to be conducted with GPR. Today, the use of GPR in identifying buried archaeological sites is a growing field in geoarchaeology (Conyers, 2014).

Five GPR grid surveys were collected using a Sensors \& Software pulseEKKO PRO GPR system with an antennae frequency of $500 \mathrm{MHz}$. The select grid dimensions can be found in Table 1. Site determination was decided from previous sediment core analysis and geoarchaeological research on the Tel. The earlier research confirmed the presence of marine and fluvial sediments associated with an estuary and/or coastline along the southwest base of Tel Akko (Giame et al., 2018).

After grid collection occurred, GPR lines were imported into GFP_Edit 4 (GPR Files and Parameters) and an axis-based grid was created. The created GFP files are then exported to a Sensors and Software GPR processing application called EKKO_Project 5. GPR profiles were processed in a software extension called SliceView. During data processing in EKKO_Project5 and SliceView gain was adjusted to between 7 to 8 . Conductive sediments affected the average velocity for each grid which was between .07 and $.08 \mathrm{~m} / \mathrm{ns}$ based on hyperbolic measurements.

\section{Results and Discussion}

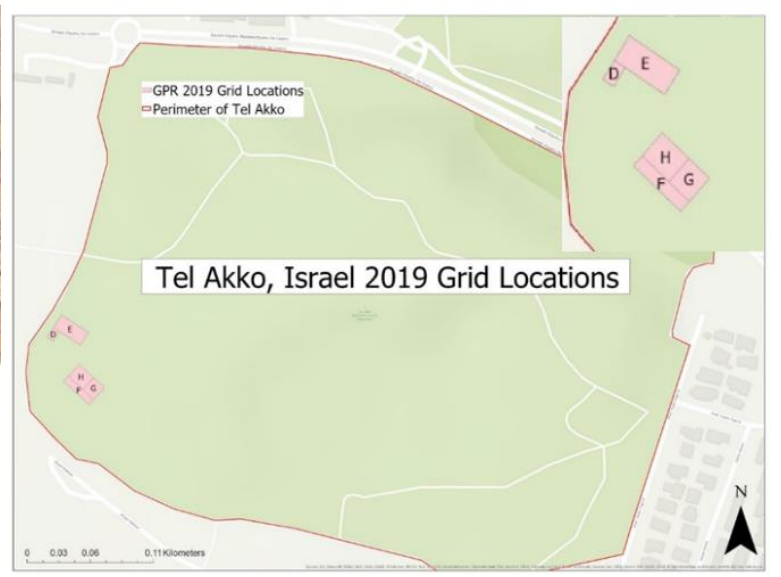

Figure 3: Grid locations at Tel Akko

SliceView planar analysis of Grid D indicates a reflection pattern located on the southwest side of the grid and starts at around seven meters and are present until the terminus of the

grid (Figures 3 and 4). Reflections patterns are continuous, hummocky to subparallel from the near surface to a depth of $0.65 \mathrm{~m}$, after which, the radar signal becomes attenuated. The reflection patterns are consistent with Kurkar sandstone. Two sediment cores were taken in the northeast and southwest regions of the grid which confirmed the interpretation and location of Kurkar being located in the southwest portion of Grid D.

Grid E was collected to the northeast of Grid D (Figure 3 and $5)$. In the grid there are regions of moderate to strong reflections patterns, which were located at a depth of 0.125 $0.175 \mathrm{~m}$. Reflection pattern geometry consists of right-angles $\left(90^{\circ}\right)$ and linear reflection patterns. Depth slices below $0.175 \mathrm{~m}$ contain a region of strong reflection patterns starting at $8 \mathrm{~m}$ on the $\mathrm{x}$-axis and $5 \mathrm{~m}$ on the y-axis. The reflection patterns within the grid mainly consist of ringing and hyperbolic features and are consistent with an interpretations of buried metal objects.

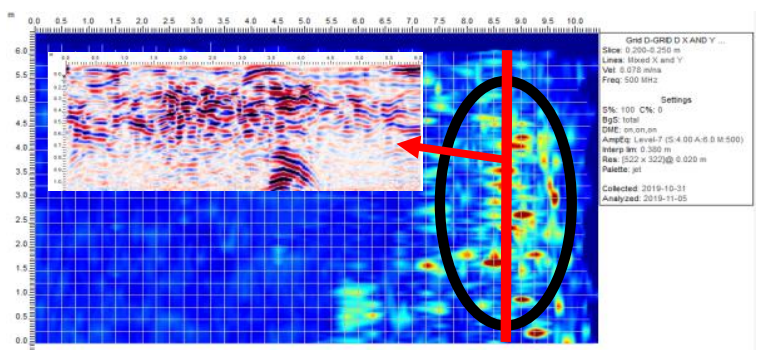

Figure 4: Planar and horizontal view of Grid D with region of Kurkar sandstone shown between around $7 \mathrm{~m}$ on the $\mathrm{x}$-axis and 0.5 $5.5 \mathrm{~m}$ on the $\mathrm{y}$-axis. Line 35 highlighted I $\mathrm{n}$ red bisects the reflection pattern region and contains hummocky to subparallel facies. 


\section{Tel Akko, Israel Subsurface Imaging}

\begin{tabular}{|c|c|c|c|c|c|}
\hline Grid Name & Gind D & GridE & Grid F & Grid G & Grid $\mathrm{H}$ \\
\hline Siep Size (m) & 0.020 & 0020 & 0.020 & 0.020 & 0.020 \\
\hline $\begin{array}{l}\text { Antennae } \\
\text { Scpuration } \\
\text { (m) }\end{array}$ & 0.25 & 0.25 & 0.25 & 0.25 & 0.25 \\
\hline $\begin{array}{l}\text { Dimensives } \\
(W \times L)(m)\end{array}$ & 1006 & $13 \times 28$ & $6 \times 30$ & $14 \times 13$ & $14 \times 17$ \\
\hline $\begin{array}{c}\text { Time } \\
\text { Window (ns) }\end{array}$ & 50 & 50 & 50 & 50 & 70 \\
\hline
\end{tabular}

Other reflection patterns noted in Grid $\mathrm{G}$ are dipping and hyperbolic reflections. Reflection patterns of Grid $\mathrm{H}$ contained regions of chaotic reflections which could be associated with uneven layering of Kurkar sandstone. The deep ringing reflections found throughout the profile are likely buried metal objects. The general stratigraphic orientation of Grid $\mathrm{H}$ are horizontal with regions of sigmoidal dipping reflections that vary in slope (Figure 7). The sigmoidal dipping to undulating reflections are similar to present day coastal environments. The pattern in Grid $\mathrm{H}$ is hypothesized to be an ancient gravel beach, which underwent periods of erosion and sediment deposition. This interpretation has been corroborated by follow-up coring.

The three contiguous grids $(\mathrm{F}, \mathrm{G}, \mathrm{H})$ were projected onto UAV imagery collected at the site (Figure 8). This approach allowed for the location of larger scale subsurface features and/or subsurface architecture to be observed. The overlain grids display a defined $90^{\circ}$ (right-angle reflection pattern that overlaps from Grid F onto Grid G. The right-angle feature is plausibly a human-made architectural structure. Other linear and circular features in the collated grid could indicate harbor infrastructure such as a quay, mole, or pier. The regions of little to no reflections in the grids are surrounded by linear and right-angle features. The low reflections area(s) are possibly regions which were once submerged by water, as the elevations of these grids is the lowest. The sloping nature of combined with a flood map created during this research corroborated the theory that this portion was likely along the estuary or coastline.

Reflection patterns within Grids F, G and H are composed of horizontal to sub-horizontal reflection patterns with some dipping horizons, as well as some regions of chaotic reflections (Figures 3, 6, 7, and 8). Grid F contains a concordant reflection pattern on line 8 from $11 \mathrm{~m}$ to $19 \mathrm{~m}$ and a shallow erosional truncation from 20-24.5m (Figure 6). Grid $\mathrm{G}$ shows horizontal layering along a reflective subsurface feature found on line 39 from $0 \mathrm{~m}-6 \mathrm{~m}$. The layer on this line possibly correlates to a clay or human made floor as the signal attenuates below this horizon indicating a change in the sediment's dielectric properties.

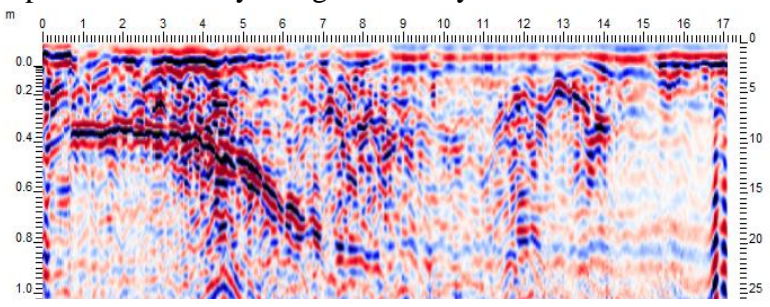

Figure 7: Line 41 of Grid $\mathrm{H}$ with pronounced erosional truncation and some hyperbolic features

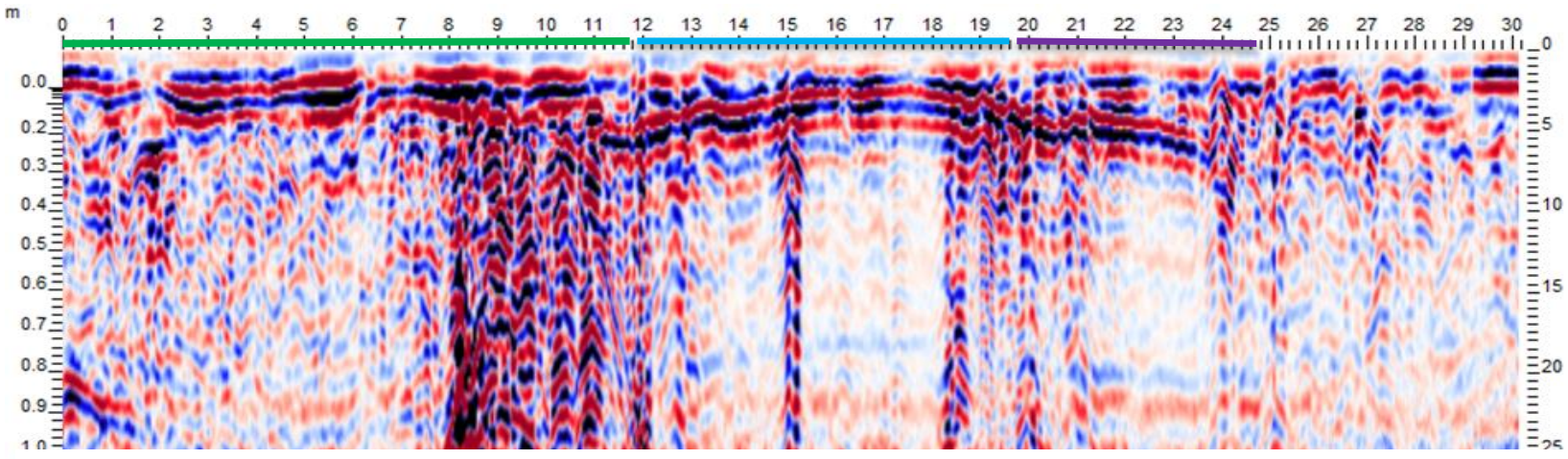

Figure 6: Stratigraphic profile of line 8 in Grid F showing an area of chaotic reflections, concordant reflections, and a possible erosional truncation. 


\section{Tel Akko, Israel Subsurface Imaging}

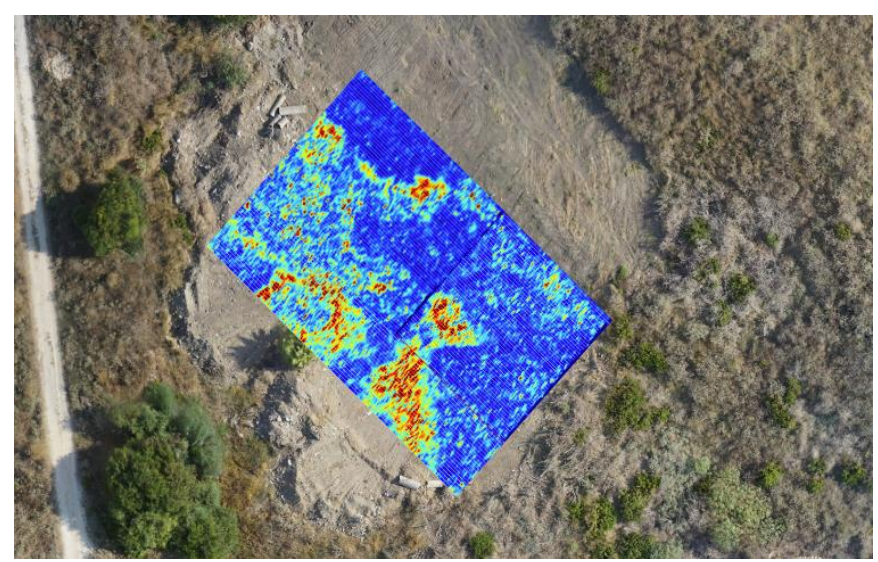

Figure 8: Grids F, G and $\mathrm{H}$ overlain with clear circular, linear, and $90^{\circ}$ reflection patterns. These reflection patterns could be interpreted as humanmade architectural features such as a quay and/or mole.

\section{Conclusion / Future Studies}

The Tel Akko project invesitgated an UNESCO ancient archaeological site along the northern shoreline of Haifa Bay. It has been hyposethized that Tel Akko was a significant port town based on textural and archaeological findings. The GPR grids collected in the project provide evidence for:

- locating Kurkar sandstone

- metallic debris (ringing noise)

- aggradational sedimentary features

- linear and $90^{\circ}$ (right-angle) reflection patterns that are interepretered as probable human-made structures either habitations and/or coastal quays/moles

- sigmoidal to undulating reflection pattern interpreted as a coastal environment - beach-like formed of sands and gravels which are similar cores taken in the area

Based on the project results, future work should include:

- sediment cores to ground truth GPR interpretations

- expansion of GPR grids and experimentation with lower frequency antennae

- additional sediment cores

- archaeological excavation at promising sites

\section{Acknowledgements}

The research was funded by the United States-Israel BiNational Science Foundation Grant Number 2016080 and the University of Wisconsin- Eau Claire's Office of Research Sponsored Program (Student/ Faculty Research Colloboration and Diversity Mentoring).

\section{References}

Artzy, M., 2012, Return to Tel Akko, its anchorages, harbor, and surroundings: Recanati Institute for Maritime Studies News, p. 5-14.

Bernd, H., and Garrison, E., 2003 Techniques in Archaeological Geology. Springer

Artzy, M., 2015. What is in a name?'Akko-Ptolemais'Akka-Acre: Complutum, 26, 205-212.

Conyers, L.B., and D. Goodman, 1997, Ground-penetrating radar: An Introduction for archaeologists: AltaMira Press.

Conyers, L.B., 2014, Interpreting ground-penetrating radar for archaeology: Left Coast Press.

Giaime, M., C. Morhange, N. Marriner, G.I. López-Cadavid and M. Artzy, 2018, Geoarchaeological investigations at Akko, Israel: New insights into landscape changes and related anchorage locations since the Bronze Age: Geoarchaeology, 33, 641-660.

Jol, H.M., and C.S. Bristow, 2003, GPR in sediments: Advice on data collection, basic processing and interpretation, a good practice guide, in C.S. Bristow, and H.M. Jol, eds., Ground penetrating radar in sediments: Geological Society, London, Special Publications, v. 211, 9-27 doi:10.1144/GSL.SP. 2001 .211 .01 .26

Morhange, C., M. Giaime, N. Marriner, A. Hamid, H. Bruneton, A. Honnorat, and M. Artzy, 2016, Geoarchaeological evolution of Tel Akko's ancient harbour (Israel): Journal of Archaeological Science: Reports, 7, 71-81, doi: 10.1016/j.jasrep.2016.03.046

Porat, N., D. Sivan, and D. Zviely, 2008, Late Holocene embayment infill and shoreline migration, Haifa Bay, Eastern Mediterranean: Israel Journal of Earth Sciences, 57, 21-31, doi:10.1560/ijes.57.1.21.

Sensors and Software, 2015, EKKO_Project GPR software processing and display, http://www.sensoft.ca/Products/Software/detailsfeatures.aspx, accessed 25 September 2018.

Vachtman, D., A. Sandler, N.Greenbaum, and B. Herut, 2012, Dynamics of suspended sediment delivery to the Eastern Mediterranean continental shelf: Hydrological Processes, 27, 1105-1116, doi: 10.1002/hyp.9265.

Zviely, D., E. Kit, and M. Klein, 2007, Longshore sand transport estimates along the Mediterranean coast of Israel in the Holocene: Marine Geology, 238, 61-73, doi:10.1016/j.margeo.2006.12.003. 